\title{
Paroxetine Measurement
}

National Cancer Institute

\section{Source}

National Cancer Institute. Paroxetine Measurement. NCI Thesaurus. Code C147410.

The determination of the amount of paroxetine present in a sample. 